\title{
FROM TLS POINT CLOUD DATA TO GEOMETRICAL GENESIS DETERMINATION OF RIBBED MASONRY VAULTS
}

\author{
L. Agustín-Hernández ${ }^{1}$, R. Argiolas ${ }^{2 *}, \mathrm{~V}$. Bagnolo $^{2}$, M. Sancho Mir ${ }^{1}$ \\ ${ }^{1}$ Department of Architecture, University of Zaragoza, Zaragoza, Spain - lagustin@unizar.es \\ ${ }^{2}$ DICAAR, University of Cagliari, Cagliari, Italy - raffaele.argiolas@hotmail.com
}

KEY WORDS: Terrestrial 3D laser scanning, Geometric analysis, Procedural modelling, Ribbed cross vaults.

\begin{abstract}
:
The contribution aims to explore the possibility of tracing the geometry of ribbed vaults from two different Mediterranean regions to a single matrix, verifying the presence of possible local variations of the same rules. In particular, the analyses are being carried out in parallel on some case studies of the regions of Sardinia in Italy and Aragon in Spain. The two case studies include the Iglesia Parroquial del Salvador la Seo in Zaragoza and the Church of Santa Lucia in Cagliari. Both constructions can be traced back to the style known as Late Mediterranean Gothic, which characterised the architecture of the countries bordering the Mediterranean basin between the 14th and 17th centuries. The two case studies chosen were almost at the extreme ends of the Late Gothic period, to determine whether some invariants sought could persist even in relatively distant periods. The analysis focused on cross vaults covering the two naves, which included a laser scanner survey in order to obtain a cloud of points of sufficient precision to carry out studies on the geometry of the vaulted systems, the identification of the intrados profiles of the ribs and therefore the definition of the curvatures and centres of all the arches making up the vaults. Finally, the results are presented by means of summary diagrams and comparison tables.
\end{abstract}

\section{INTRODUCTION}

The entire history of construction is characterised by the presence of geometric rules used to govern architecture. The geometric rule, and consequently the proportional one, were invested with the role of real sciences, even before the advent of construction science; the geometric rule played such a central role that, despite the progress of the physical and mathematical sciences, due to the simplicity and aesthetic canon that distinguish it, it still remains for a long time in architectural construction practice (Rondelet, 1832).

An emblematic case are diagrams for the layout of Gothic vaults, elements often quite complex which in historical treatises are brought back to relatively simple graphic schemes. Consider Villard's travel notebook (Villard De Honnecourt, XIII sec.), perhaps the first example of a geometric construction scheme put down on paper.

He affirms with undeniable certainty rules that have not been scientifically (for us) demonstrated, and this is not for lack of mathematical knowledge, as demonstrated by Giordano Nemorario's reasoning on perpetual motion (Clagett, 1981), but for conviction, almost faith, in the geometric rule.

Villard formulates his rule of the three arcs on the convenience of keeping the curvature of the arcs at the base of the geometric construction constant. Villard's is only the first example of a long series of geometric constructions that find their genesis in the identification of the curvatures of the ribs. The importance of the curvatures of the ribs is such that Willis (1842) asserts that knowing these curvatures is sufficient to be able to completely define the entire geometry of the vault.

During the fifteenth and sixteenth centuries the Sardinian culture underwent important changes with the intense process of Hispanization. The island's architecture is also strongly influenced by the Spanish one and today in Sardinia there are numerous testimonies of this era, especially in religious architecture.
The question remains whether the practices and models of Iberian architecture are literally imported into Sardinia or whether these are declined on the island with their own distinctive variations and peculiarities. An architectural component that can certainly give us a measure of the Spanish influence in Sardinian architecture is that of the ribbed vaulted systems that had widespread diffusion on the island in those centuries.

The aim of the presented contribution is to search for proportional and geometrical characteristics that the Sardinian late Gothic systems have in common with those of the region of Aragon, precisely because of the strong cultural and architectural influence that the latter had on Gothic architecture in Sardinia. To do this, surveys and geometric analyses were carried out on two case studies, the Church of Santa Lucia in Cagliari and the Chapel of San Miguel in Zaragoza.

In both churches there are two cross vaults in succession covering the two naves. The analysis focused on these vaults, which included a laser scanner survey in order to obtain a cloud of points of sufficient precision to carry out studies on the geometry of the vaulted systems. The analysis includes the identification of the intrados profiles of the ribs and therefore the definition of the curvatures and centres of all the arches making up the vaults.

Finally, the results are presented by means of summary diagrams and comparison tables.

The summary representation chosen is based on the work of Juan Carlos Palacios in his "La Cantería Medieval" (2009), in which the author collects the methods of representation used by various treatises of the 16th century; this type of representation involves matching the planimetric diagram to the ribs, or just the soffit profiles, by flipping them over and showing the various comparisons between the curvatures as well as the start and end points of each profile.

\footnotetext{
* Corresponding author
} 


\section{STATE OF THE ART}

\subsection{Digital survey techniques}

The analysis of complex architecture such as gothic vaulting systems requires precise dimensional data. The analogue instruments, such as measuring rods or plumb lines, used in traditional surveys have two major limitations: accessibility to the vaults to be surveyed and, if accessibility is via scaffolding, for example, an excessively high margin of error. The introduction of digital surveying systems, in particular laser scanning and photogrammetry, offers not only a higher degree of precision and greater speed, but also the possibility of surveying very high vaults from ground level.

These advantages, combined with ease of use and availability, have made laser scanning and photogrammetry fundamental tools for surveying historical heritage. In the case of vaulted systems, it is now possible to survey both their details and their entire configuration at the same time, with levels of precision in the order of a millimetre; a level of detail that, under the right conditions, can be seen in both the point clouds and the resulting meshes (Corns et al., 2017; Tallon, 2014). The digital nature of the information collected offers the additional advantage of being able to apply data analysis and manipulation techniques that were previously impossible (Di Mascio, 2015).

As mentioned above, the time needed to complete the surveys is also considerably reduced thanks to digital tools, from weeks in the case of manual surveys to just a few days, with a significant improvement also in terms of error elimination (Richens \& Herdt, 2009).

In spite of the advantages analysed here, the transition from analogue to digital methods does not eliminate the need to collect documentary information in order to design the survey in the best possible way, which is the only way to achieve an acceptable level of accuracy (Mitchell, 1992).

This is fundamental when analysing vaulted systems; although at first glance these may appear to have particularly simple geometries, the accuracy of digital survey systems has often revealed a complexity far greater than initially assumed. An example is the analysis that Willis (1842) suggests for the definition of the curvatures of the ribs in the vaults and the identification of the centres of curvature in relation to the lines of imposts (Figure 1); a real verification of these theories, extremely difficult in the past, is now accomplished thanks to digital survey techniques (Webb et al., 2016).

This is possible thanks to the versatility of these survey systems, which allow us to obtain two-dimensional models, such as orthophotos and sections, and at the same time threedimensional models, such as point clouds and meshes, which can not only be analysed but also navigated (Bagnolo et al., in press).

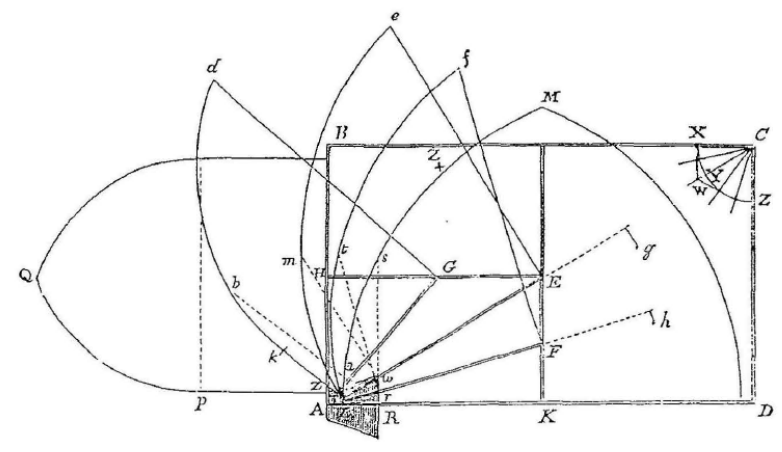

FIG.10.

Figure 1. Curvatures of the ribs in a drawing by Willis.

\subsection{Geometrical analysis of the vaults and their representation}

In the transition from High to Late Gothic, the representations of vaults became more complex and elaborate, while techniques tended to facilitate their layout and construction. The search for standardisation and simplification characterises all Gothic architecture, and in this sense the tendency to build complex ribbed vaults using as few curvatures as possible is emblematic (Tellia, 2013).

Analysing the historical treatises in which there are references to Gothic vaulting systems, a particularly frequent technique of representation seems to emerge: the proposition of the planimetric scheme connected, by means of projections, to the traces of the ribs overturned on one side of the plan; these traces appear both as complete representations and as simple intrados profiles.

One reason for the choice of this type of representation technique is undoubtedly the importance of keeping the curvatures as constant as possible; this is clear from the very first examples of geometric constructions indicated for the construction of vaulted systems, first and foremost Villard's socalled rule of three arches (XIII sec.).

Drawings of plans and inverted curvatures are widely used not only in texts proposing vault construction techniques but also, in later times, in analytical studies; we can therefore find examples of treatises that use this technique to define the shapes of vaults, others to indicate how stones should be cut or even to carry out static analyses.

An interesting example comes to us from Ribes (1708) who proposes a collection of 40 plates, each containing the description of a vault, organised according to an increasing complexity (Figure 2).

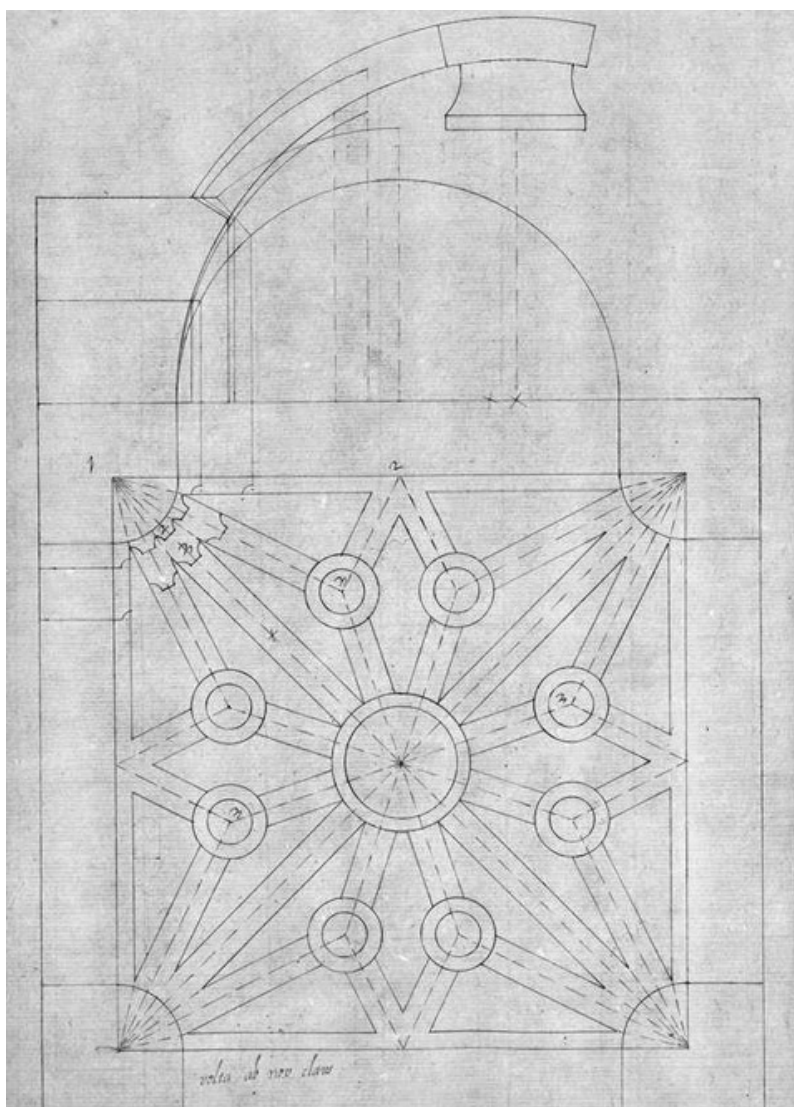

Figure 2. One of the plates by Ribes for representation of the vaults. 
In particular, his drawings respect polar or axial symmetries, according to coordinated axes or according to diagonals; the keys are represented in elevation and the ribs lie on planes perpendicular to the plane of the impost (Tellia, 2013).

Ribes reworks and re-proposes some of the concepts already proposed in the past by illustrious examples such as Rodrigo Gil, Vandelvira and Gelabert, all from the mid-1500s.

Contemporaries of the latter are also Herman Ruiz and Francisco de Luna, both authors of interesting works on stereotomy and on the cutting of ashlars; in particular, in 1560 Ruiz represents a Gothic vault by drawing the plan and the elevations of the arches, of which he only reports the directions (Navascués Palacio, 1974).

The last example to be given is that of the drawing of vaults for static analysis. Starting with the studies of Willis (1835), the first to propose a theory on the possible geometric genesis of the ribs (Huerta, 2009), techniques of graphic analysis for their static verification were developed over time (Planat, 1887; Wittmann, 1879).

Precisely because of the importance of his theories on geometric genesis, Willis is recognised as a central figure in the study of vaulted systems, with particular reference to the pivotal role given to curvatures, going deeper into what was described by De l'Orme (1561), one of his main references (Huerta, 2016).

\section{CASES OF STUDY}

\subsection{The Chapel of San Miguel (la Parroquieta), Zaragoza}

The Chapel of San Miguel, known under the nickname "La Parroquieta", built on the site of the old mosque of Saraqusta, is located at the northwest end of the Cathedral of La Seo del Salvador, in Zaragoza and has an independent access to the Cathedral itself (Figure 3).

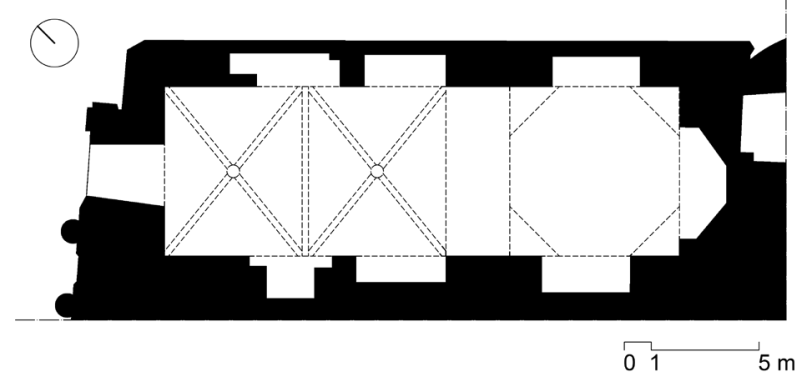

Figure 3. Plan of the Chapel of San Miguel.

"It is actually the funeral chapel commissioned by the Archbishop of Zaragoza, Don Lope Fernández de Luna" (Borras Gualis et al., 2019, p. 94). With approximate dimensions of $22.50 \times 10.00 \mathrm{~m}$ and a height of $17.00 \mathrm{~m}$ to the viewpoint that finishes the building, has a nave of two sections covered by ogive vaults, made of stone, a rare occurrence in the city of Zaragoza where there are no quarries nearby and most of the heritage architecture is in brick and plaster. The perimeter walls are of double leaf containing stairs and corridors, covered by brick barred bovedillas that in turn lock the outer leaf with the interior, which avoids the construction of buttresses.

"The work was carried out between 1374 and 1381, responding to a rectangular plan with two sections covered with ribbed vaults and the main chapel opens by pointed arch and is covered with magnificent Mudejar armor" (López Guzmán, 2016, p. 274) (Figure 4)

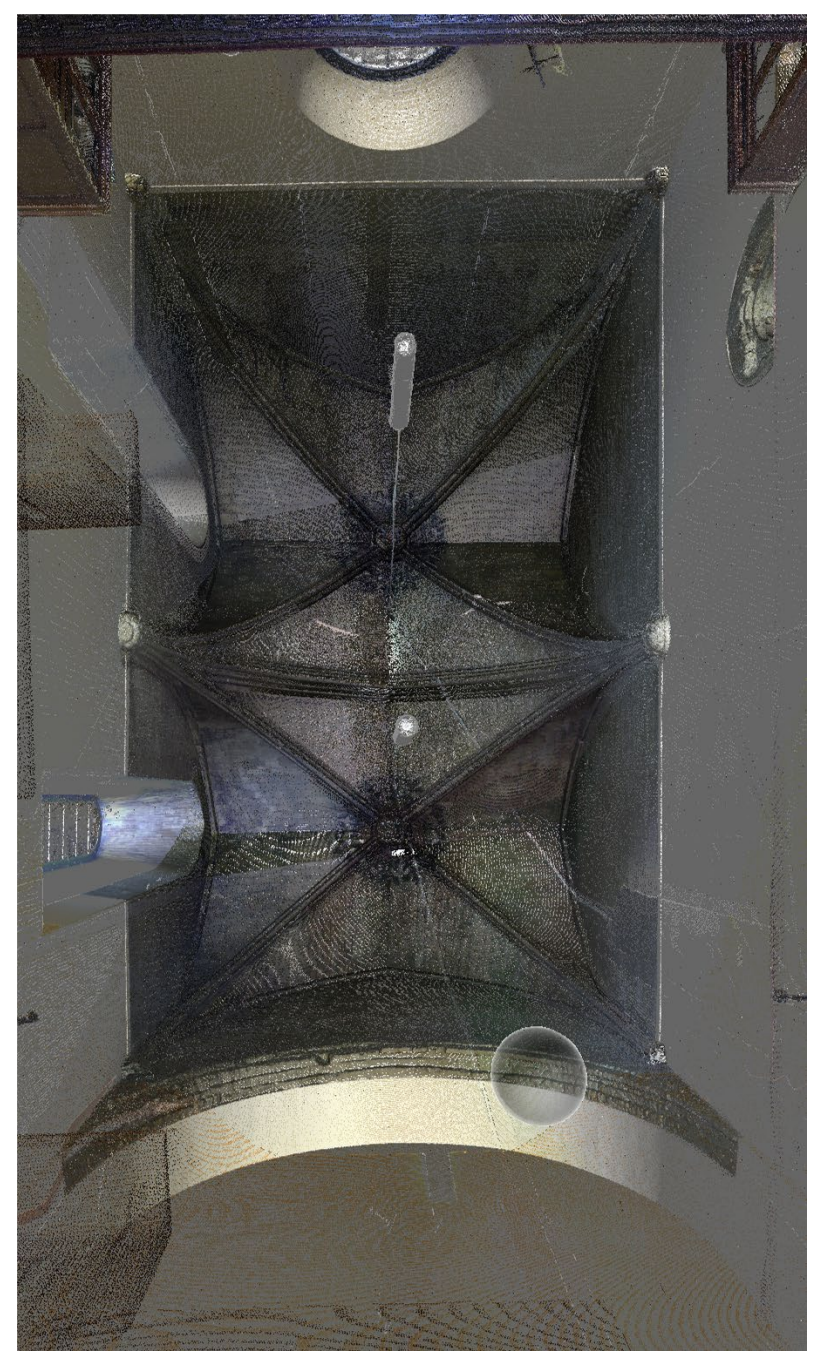

Figure 4. The vaults covering the navi of the Chapel of San Miguel.

In height the building is divided into three parts: in any case, that space of approximately square plant of $10,00 \mathrm{~m}$ of side, are the chapiters of what could have been a vault of cross in stone factory, in the present day two arcs of diaphragm support a oneway floor beams.

It is accessed from the ground floor behind the solid arch where the sarcophagus of Don Lope is located and through the north wall.

The second space at street level is the chapel, already described, with a double height, because at the top over the access is the choir, third space of this building, which, like the basement, is accessed by stairs between the north wall, the double leaf of the walls particularly interesting from a constructive point of view, it had another series of corridors such as the one that linked the cathedral with the Archbishop's Palace, of which photographs are still preserved.

Outside, we can observe a brick factory of the most worked and valuable in Aragon, contrasts with the interior by the materials used from a constructive point of view out of the decorative elements, where brick and ceramics are used almost exclusively, in front of the stone inside. The complex is topped off with an accessible upper gallery, over the vaults of the chapel and over this one covered with Arabic tile (Figure 5). 


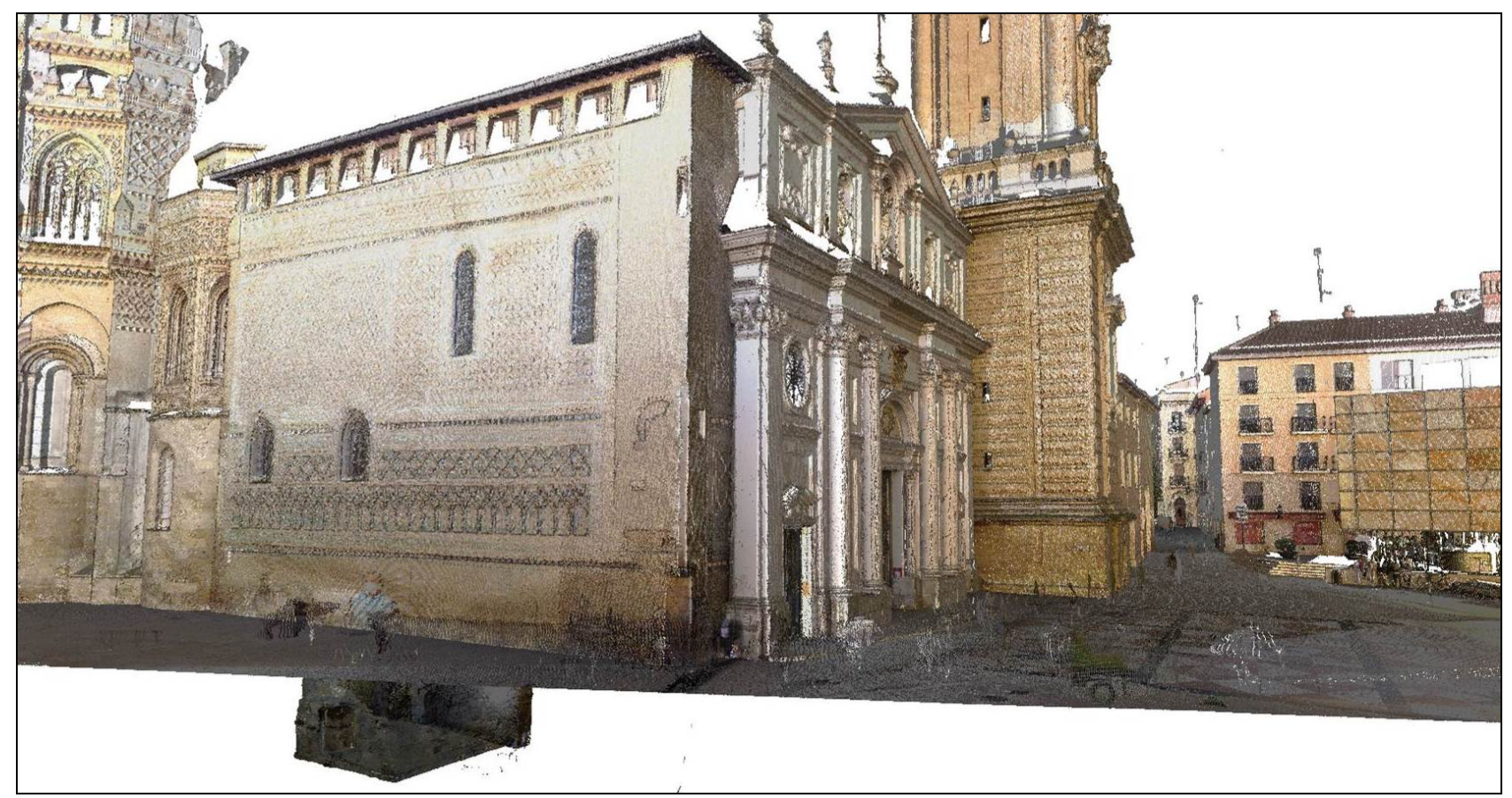

Figure 5. External view of the Chapel of San Miguel.

\subsection{The church of Santa Lucia, Cagliari}

The church of Santa Lucia (Figure 6), part of the Convent of the Clarisse Nuns, is located in Cagliari in the historic district of Castello, an important area of the city which until the 19th century housed all the main powers of the city government.

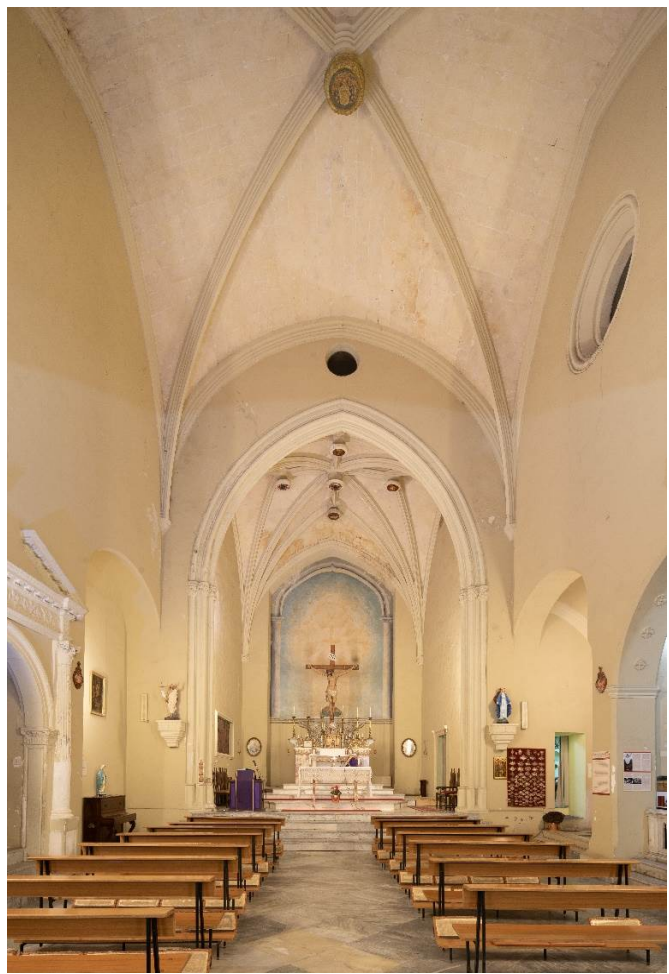

Figure 6. A view of the nave and presbytery of the Church of Santa Lucia.

In the absence of reliable documentary sources, it is not possible to date the building with precision, but the presence of numerous elements that unite it with other churches in the same district ascribes it to the end of the 16th century. A useful document for dating the church of Santa Lucia is certainly the contract for the construction of the nearby church of Santa Maria del Monte di Pietà, dating back to 1571, in which we find the explicit request to build the vault of the presbytery with shapes similar to those of the stellar vault of the presbytery present in the Church of Santa Lucia (Mereu, 1999).

The church, entirely built in limestone masonry, consists of a single nave divided into two vaulted bays ending in a quadrangular presbytery with a lower section than the nave, without transept and with two side chapels (Figure 7).

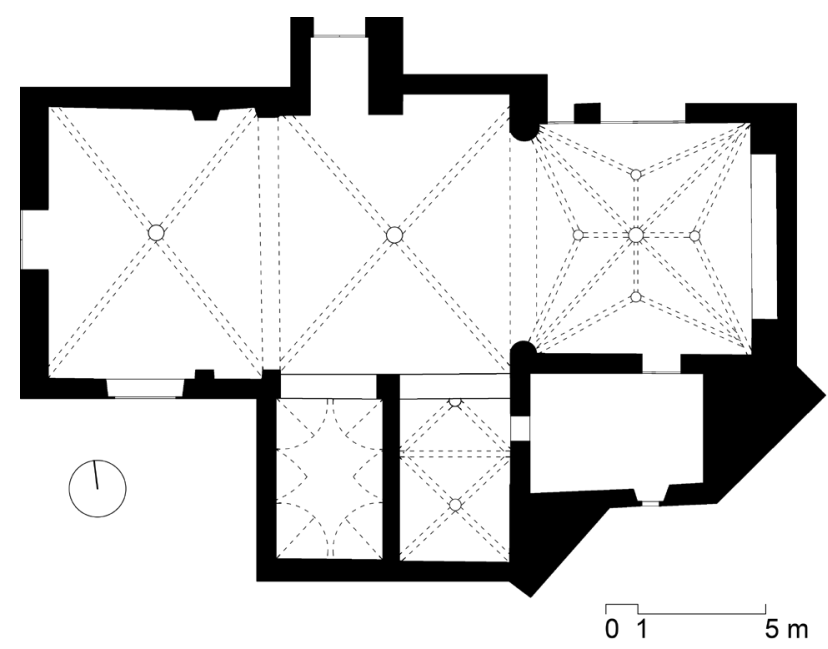

Figure 7. Plan of the Church of Santa Lucia.

The molded ribs of the vaults branch off from worked corbels. The keystones are in the form of a pendulous gem and constitute the most worked and decorative element of the vaulted system. The presbytery is shaped like a capilla mayor and is surmounted by a star vault with five keystones set on a quadrangular base. The presbytery vault of Santa Lucia adheres to the languages of the same architectural avant-gardes of the central Iberian and Mesoamerican kingdoms (Schirru, 2013). 
In the first vaulted bay, above the current entrance, there is a high choir, supported by a net vaulted ceiling with lunettes, built in later times to replace the original vaulted system of which two shutters of the arch still in the masonry can be identified. On the right for those entering from the main entrance, there are two rectangular side chapels, while on the left there were openings, now obliterated, which connected the church with the convent, only a connecting portal is still present. The first chapel has a barrel vault with lunettes, while the second chapel is covered by a ribbed cross vault to which is added a half cross vaulted ceiling. The sacristy room adjacent to the presbytery is covered with a barrel vault. All the perimetral and the diaphragm arches on which the late Gothic vaults are set are ogival arches.

The ribbed cross vaults of the church of Santa Lucia show a minimalism typical of simple cruises, familiar to Catalan, Valencian, and Majorcan architectural traditions. In the decorations we find instead a mixture that takes up the Spanish Gothic and the influences of the Italian Renaissance, known as the Plateresque style, present in capitals, cornices, and balustrades (Schirru, 2014).

\section{METHODOLOGY}

The first step is the collection of historical and documentary data; this is indispensable for a correct interpretation of the characteristics of the churches and for planning surveys. In addition to the necessary historical and documentary investigations, laser scanning surveys were carried out on both buildings. In some cases, photogrammetry was used to survey specific details or for the outside of the buildings, when laser scanning appears too difficult.

The aim of the research is to identify variants and invariants of the geometries governing the two case studies with the intention of increasing their number in subsequent phases.

Carried out the survey and processed the point clouds, a first analysis was made about the planimetric scheme, in order to find out the main features and dimensions of the plans. this phase aims to identify possible symmetries, both polar and axial, with which to define the plan underlying the synthesis diagrams. The study of curvatures of the arches was carried out sectioning the point clouds with vertical plans; according with theorical rules from treaties in fact the profiles of the arches should lie in a plan perpendicular to spring plan. One section for each arch was made.

Using CAD software was possible to draw best-fitting arches, corresponding with intrados profile of the ribs; curves so defined were detailed with their radius and position of the centres, related to the spring plan. All resulting profiles are drawn along the plans according with drawings previously illustrated.

The final step, the comparison between the case studies, is carried out means tabular summary of main characteristics of the vaults: symmetries, dimensional ratios, curvature radii, and elevation of the centres.

\subsection{Analysis of the Chapel of San Miguel}

Three-dimensional modelling of the interior space of the chapel has been used for the geometric analysis of the vaults, using a laser scanner of the Faro model Focus 150, with 9 parking spaces on the ground floor, 4 additional for the choir at the top +2 for the staircase giving access and 3 more for the crypt of the basement +2 additional for the stairway down, to complete the work has also scanned the exterior of the building, complemented by series of low-level ground and aerial photogrammetry data capture with drone (Figure 8).

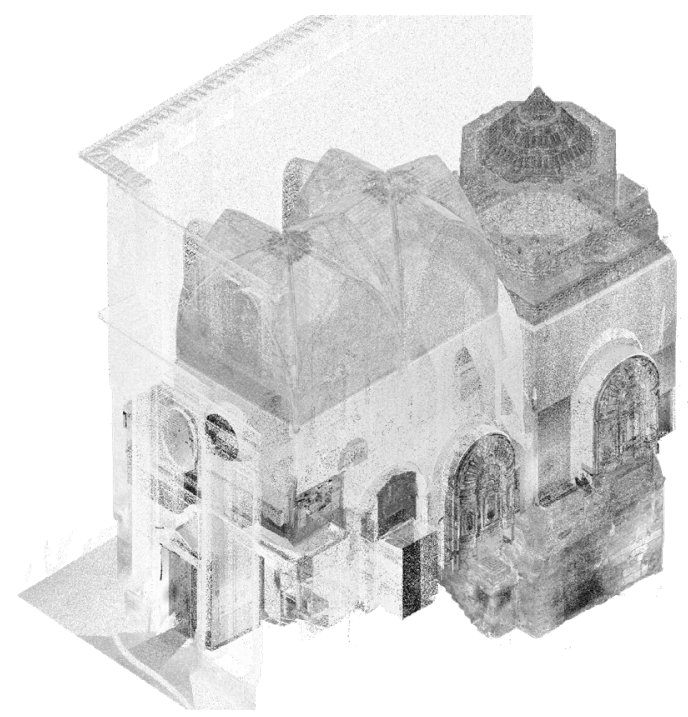

Figure 8. Point cloud digital model of the Chapel of San Miguel.

With the data obtained, the point clouds observed in the figures have been generated, which, once inserted in a cad program, by cutting them and the location of the coordinate reference system in the planes containing each arc, their mounts have been delineated to obtain the geometric characterization of the internal Gothic vaults (Figures 9-10).

The representation of the traces and mounts has been done by delineating the projection in plan, as well as the intrados of the arches lowered in true magnitude, a method that allows a quick reading and facilitates the comparison of the traces of different vaults (Palacios Gonzalo, 2009), already reported by various treaties of the sixteenth century (Figure 11).

These are two simple cross vaults that cover a rectangular space with a light of $6.34 \mathrm{~m}$ and a distance between supports of 5.25 $\mathrm{m}$, for whose comparative analysis we will precisely define the nerves, because the cross vaults are defined geometrically thanks to the definition of linear elements, the arches (Rabasa, 2013). The transept is resolved by two pointed arches with their centre of curvature on the fascia line and a radius of $5.2 \mathrm{~m}$. The perpiaño (head) arch also has its centre on the fascia line and a curvature practically equal to that of the cruiser arches of $5 \mathrm{~m}$, while the form arch is stilted with the centre to $90 \mathrm{~cm}$ on the spring line and a curvature of radius $4.73 \mathrm{~m}$. The longitudinal rampant is straight with a height difference of $18 \mathrm{~cm}$ between ends and the transverse rampant is straight and flat as the height difference between ends is only $6 \mathrm{~cm}$.

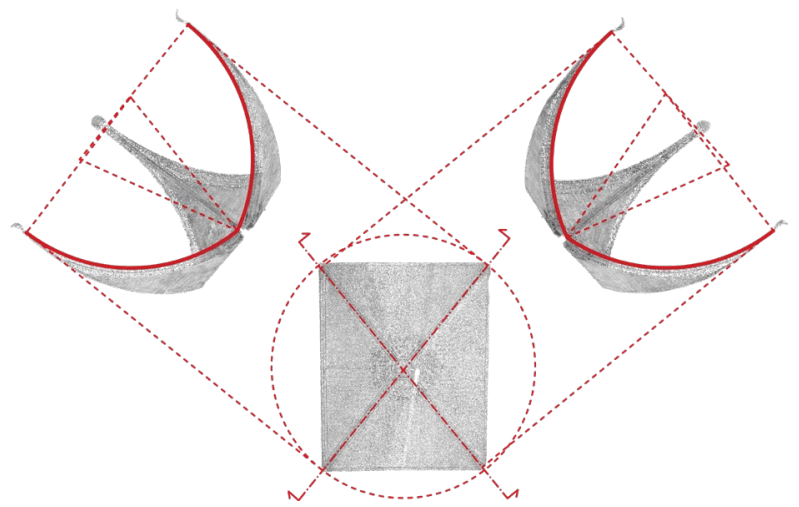

Figure 9. Definition of curvatures and centres of diagonal arches of one of the vaults of San Miguel. 


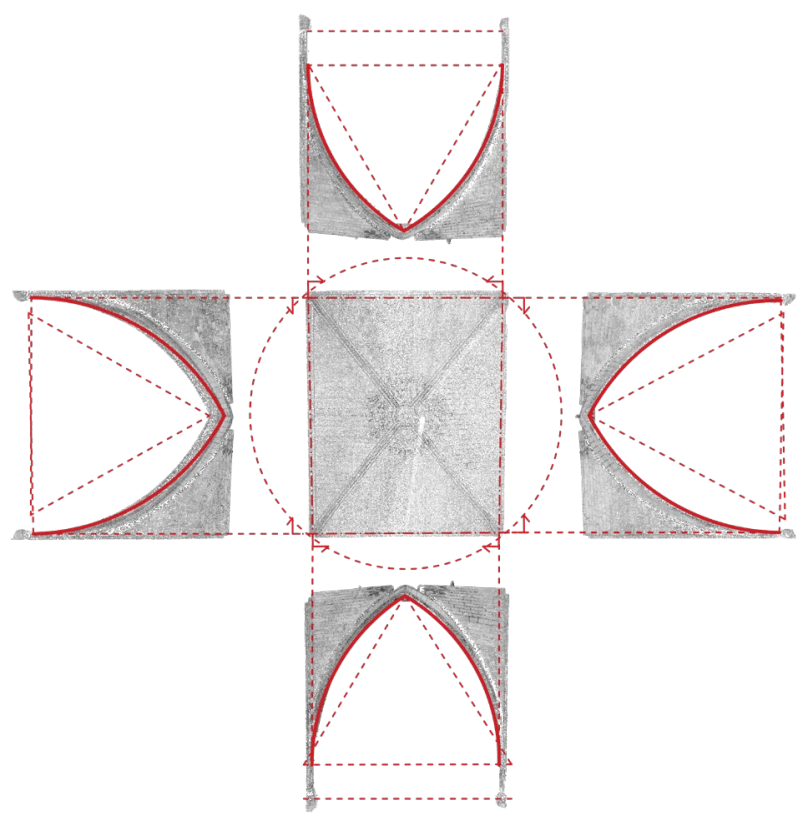

Figure 10. Definition of curvatures and centres of perimetral arches of one of the vaults of San Miguel.
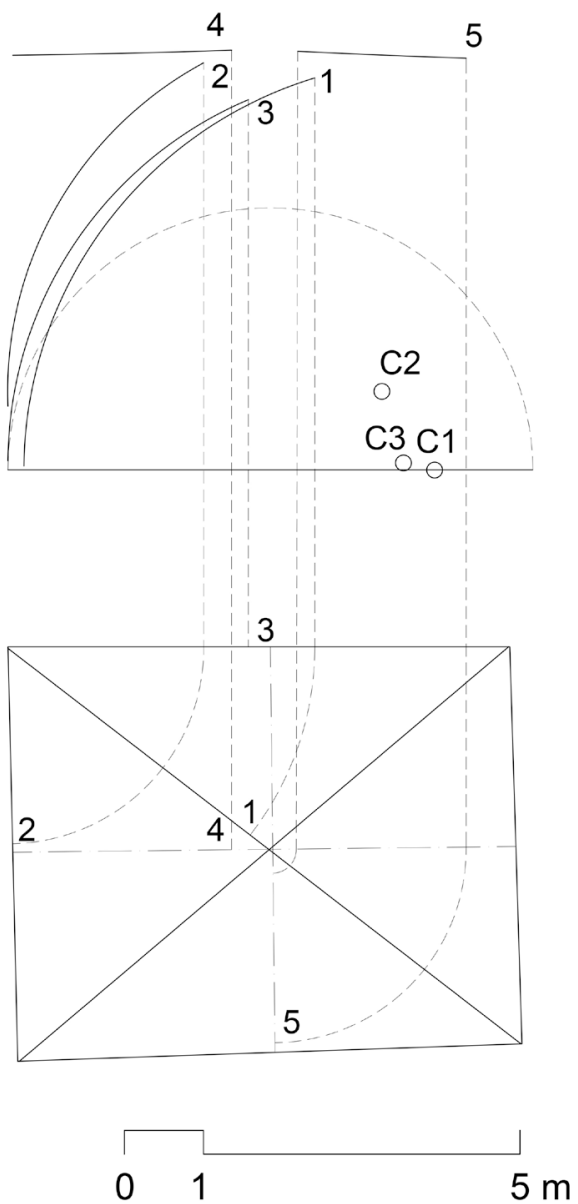

Figure 11. Schematisation of the geometries of one of the vaults of San Miguel.

\subsection{Analysis of the Church of Santa Lucia}

The surveys of the church of Santa Lucia were conducted through the integration of direct and digital surveys; in particular all the principal spaces were laser scanned, as well as the facade of the building. The scans were made with the DHS 7000 , a Leica phase-based scanner with a field of view of $360^{\circ} \times 270^{\circ}$ and a maximum scan rate of one million points / sec. The survey operations included 11 pick-up points, for a total of 1.8 billion points (Figure 12); the resulting scans were processed using Leica Cyclone software, to obtain structured data. The subsequent cleaning, segmentation and sectioning of the clouds was carried out using CloudCompare software, from which it was possible to extract plan and elevation views and the various sections required.

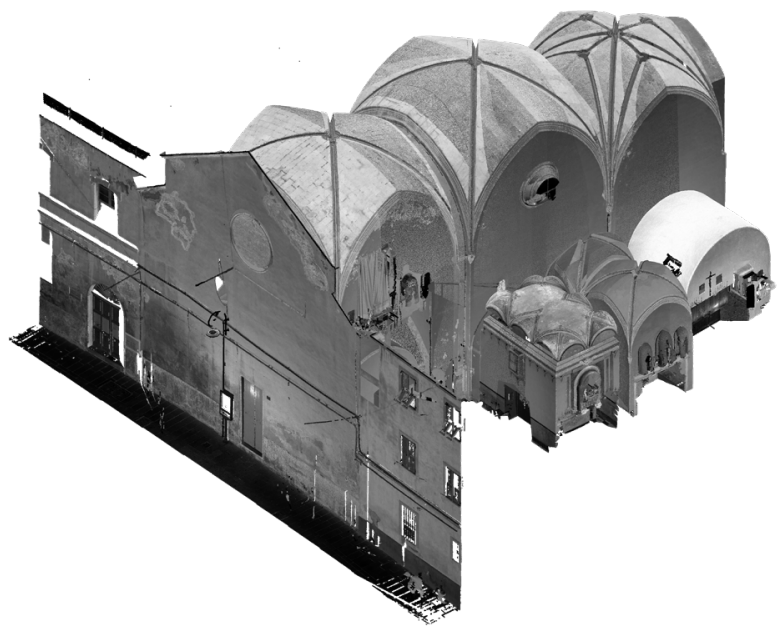

Figure 12. Point cloud digital model of the Church of Santa Lucia.

The drawings thus obtained were analysed using a CAD software, on which the geometric studies of the plans and their synthesis were carried out, as well as the analysis of the curvatures of the ribs. As already mentioned, the aim was to define for each rib and ridge line, the intrados profile, the radius of curvature and its centre (Figures 13-14).

The information obtained was finally synthesised according to the graphic representation early described (Figure 15).

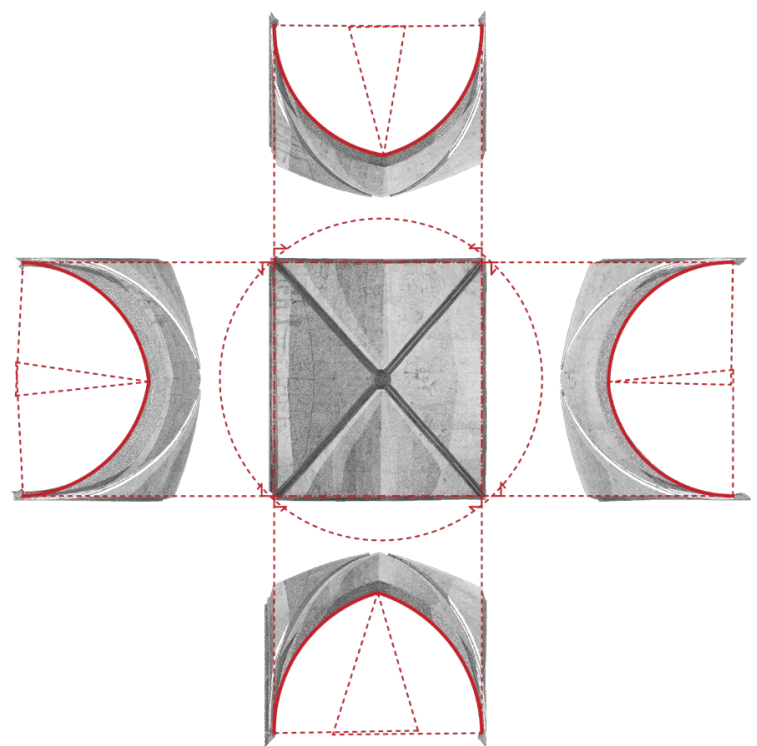

Figure 13. Definition of curvatures and centres of perimetral arches of one of the vaults of Santa Lucia. 


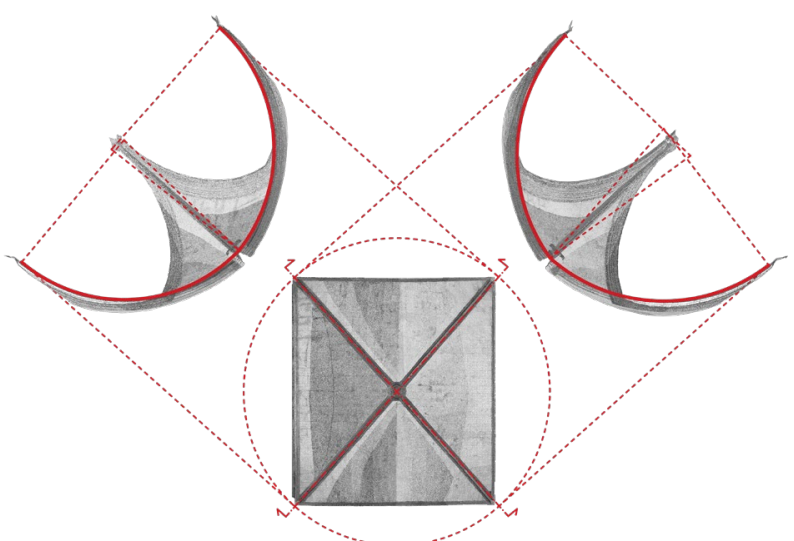

Figure 14. Definition of curvatures and centres of diagonal arches of one of the vaults of Santa Lucia.

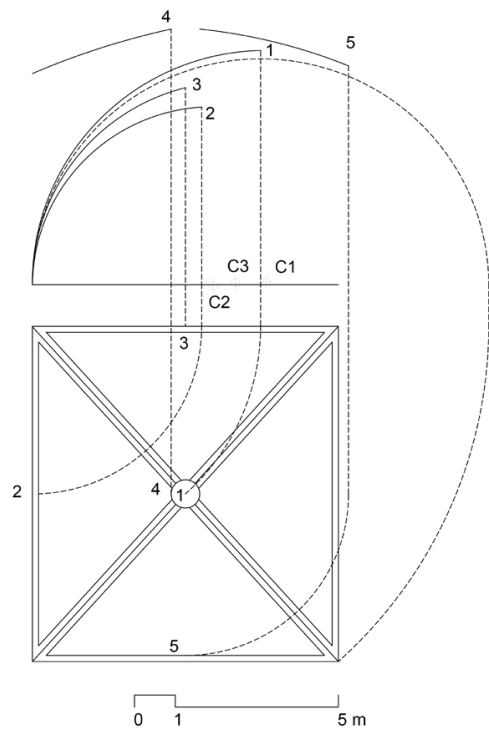

Figure 15. Schematisation of the geometries of one of the vaults of Santa Lucia.

The last step is the compilation of a summary table of the main characteristics detected (Table 1), in order to have not only an overview of the properties of the vaults analysed, but also to facilitate the subsequent comparison phase.

\section{CONCLUSIONS}

Starting from the hypothesis of the existence of strong analogies between the complex vaulted systems of the so-called "Mediterranean Gothic" in Italy and Spain, the research begins with the analysis of two case studies of ribbed ogival cross vaults identified in two churches in the regions of Aragon and Sardinia. In the historical treatise, a fundamental assumption for the definition of ideal reference models, the articulation of the geometric characteristics that govern the different parts of the cross vaults can be defined on the basis of certain recurring parameters; these features in the workflow become the initial parameters of a generative algorithm capable of modelling the geometry of all the different components of the ribbed cross vaults of the two churches (Bagnolo \& Argiolas, 2021).

In this first phase of the research, it was decided to identify two case studies that proposed solutions for ribbed cross vaults with ogival arches chronologically distant from each other and with geometries that in the first instance could be traced back to two different models proposed by historical treatises.

In our study, we therefore considered an example of a crossribbed vault with straight ridgelines (Zaragoza) and a crossribbed vault with curvilinear ridgelines (Cagliari). This choice becomes fundamental when one not only wishes to carry out a comparative analysis of the geometries that characterise the two vaulted systems, but mainly when one wishes to verify the adequacy and effectiveness of the parameters identified at the basis of the process of analysis and procedural modelling.

Apart from the obvious differences mentioned above, the two specific cases have several similarities: in both cases of study, the individual vaults present a precise axial symmetry with differences in curvature between the two halves of the same arch of less than $3 \%$; furthermore, with a few exceptions, which will merit future analysis, the radii of curvature in the same vaulted system present maximum variations of less than $10 \%$ (Table 1).

These two factors would seem to confirm the desire for standardisation in Gothic constructions. Finally, all of the vaults analysed, although of varying consistency, have raised ridge lines.

In conclusion, in spite of the differences existing between the two examples investigated, deriving primarily from the choices made during the identification of the two case studies, the results obtained allow us to conclude that even in the presence of ogival cross vaults with different geometric characteristics, the initial parameters that allow us to conduct the geometric analyses of the surfaces remain the same.

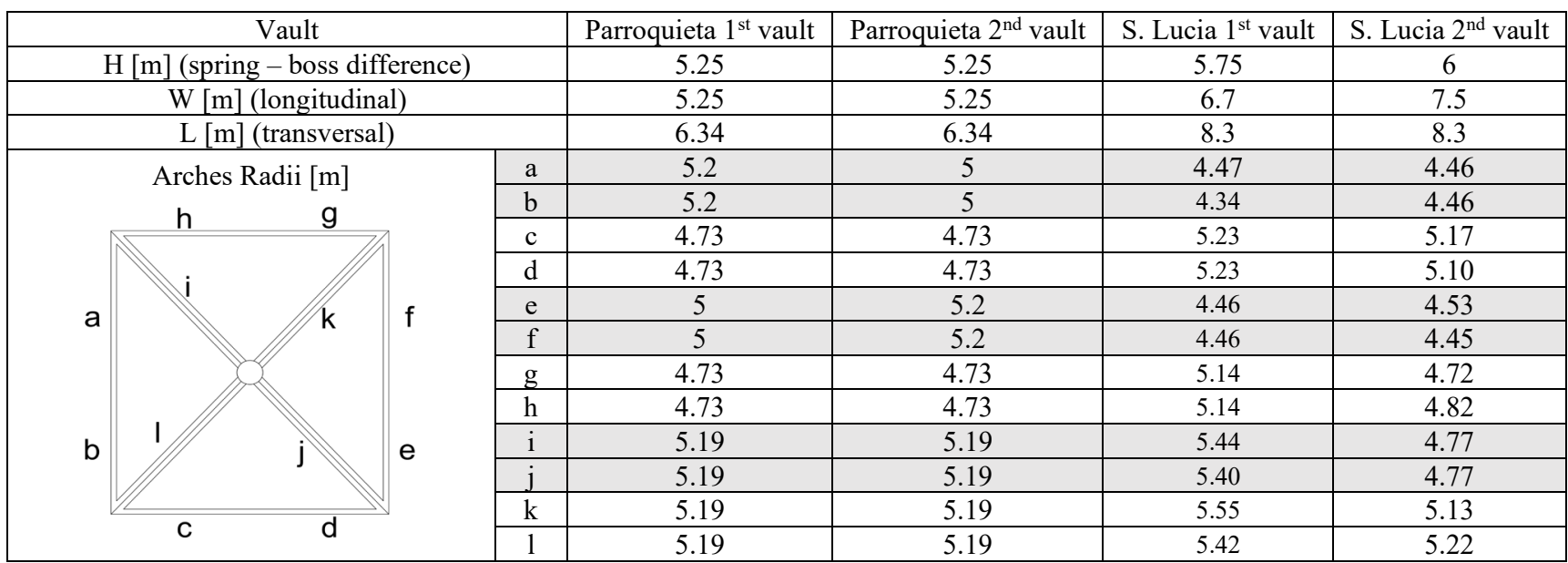

Table 1. Dimensional data of the vaults and arches radii, the coupled arches are enlightened in grey. All dimensions are in meters. 


\section{ACKNOWLEDGEMENTS}

The 3D laser scanning of the Church of Santa Lucia was carried out at LabMAST (Laboratory for historical and traditional materials and architectures), University of Cagliari, Department of Civil-Environmental Engineering and Architecture (DICAAR). LIDAR point cloud product by Andrea Dessì and Sergio Demontis.

\section{REFERENCES}

Bagnolo, V., \& Argiolas, R. (2021). Scan-to-BIM Process Versus 3D Procedural Modelling of Gothic Masonry Vaults. In From Building Information Modelling to Mixed Reality (pp. 1731). Springer.

Bagnolo, v., Argiolas, R., \& Paba, N. (in press). Communicating architecture. An AR application in Scan-toBIM processes. Representation Challenges: Augmented Reality and Artificial Intelligence in Cultural Heritage and Innovative Design Domain.

Borras Gualis, G. M., Pradinas, P. L., \& Mogollon Cano-Cortes, P. (2019). El Arte Mudejar: La estetica islamica en el arte cristiano (2 ed.). Museum Ohne Grenzen (Museum with No Frontiers).

Clagett, M. (1981). La scienza della meccanica nel Medioevo. Feltrinelli.

Corns, A., Devlin, G., Deevy, A., Shaw, R., \& Shine, L. (2017). 3D-ICONS Ireland-Fulfilling the potential of a rich $3 \mathrm{D}$ resource. Internet archaeology, 43(2), 1-7.

De L'Orme, P. (1561). Nouvelles inventions pour bien bastir et a petits fraiz. Federic Morel.

Di Mascio, D. (2015). Analytical drawings of architectural built heritage'. Proceedings of the 12th Conference of the European Architectural Envisioning Association (EAEA), Envisioning Architecture: Imag, Perception and Communication of Heritage,

Huerta, S. (2009). The debate about the structural behaviour of gothic vaults: From Viollet-le-Duc to Heyman. Proceedings of the Third International Congress on Construction History,

Huerta, S. (2016). Willis's sources on gothic vault construction. In.

López Guzmán, R. (2016). Arquitectura mudéjar (3rd ed.). Cátedra.

Mereu, S. (1999). Per una storia del Tardogotico nella Sardegna meridionale: nuove acquisizioni e documenti d'archivio. Studi Sardi, 31, 1994-1998.

Mitchell, W. (1992). The Reconfigured Eye. Visual Truth in the Post-Photographic Era. cambridge: Massachussets. MiT Press.

Navascués Palacio, P. (1974). El libro de arquitectura de Hernán Ruiz, el Joven.

Palacios Gonzalo, J. C. (2009). La cantería medieval: la construcción de la bóveda gótica española. Munilla-Lería.
Planat, P. (1887). Pratique de la mécanique appliquée a la resistance des matériaux (Vol. 2). Aux Bureaux de La construction moderne.

Rabasa, E. (2013). Estereotomía: teoría y práctica, justificación y alarde. Inf. Constr., 65(Extra-2), 5-20. https://doi.org/10.3989/ic.13.014

Ribes, J. (1708). Llibre de trasas de vias y muntea.

Richens, P., \& Herdt, G. (2009). Modelling the Ionic capital.

Rondelet, J. B. (1832). Traité théorique et pratique de l'art de bâtir: Planches; 5 (Vol. 5). Rondelet Fils. https://books.google.es/books?id=GnkOAAAAYAAJ\&printsec $=$ frontcover $\& \mathrm{hl}=\mathrm{it} \# \mathrm{v}=$ onepage $\& \mathrm{q} \& \mathrm{f}=$ false

Schirru, M. (2013). Il monastero di santa Lucia a Cagliari e l'architettura di clausura nella prima epoca moderna.

Schirru, M. (2014). I sistemi voltati nelle architetture religiose della Sardegna tra il Cinque ed il Seicento: tecniche costruttive e varianti estetiche. Lexicon. Storie e architeture in Sicilia e nel Mediterraneo, 18, 81-87.

Tallon, A. (2014). Divining Proportions in the Information Age. Architectural Histories, 2(1).

Tellia, F. (2013). Las bóvedas de crucería en el Llibre de trasas de viax y muntea de Joseph Ribes. Actas del Octavo Congreso Nacional de Historia de la Construcción. Madrid,

Villard De Honnecourt. (XIII sec.). Livre de portraiture. Paris National Library. https://gallica.bnf.fr/ark:/12148/btv1b10509412z/f1.image

Webb, N., Buchanan, A., \& Peterson, J. R. (2016). Modelling medieval vaults: Comparing digital surveying techniques to enhance our understanding of gothic architecture. ECAADE 2016: COMPLEXITY \& SIMPLICITY, VOL 2, 493-502.

Willis, R. (1835). Remarks on the Architecture of the Middle Ages: Especially of Italy. J. \& JJ Deighton.

Willis, R. (1842). On the construction of the vaults of the Middle Ages. Royal Institute of British Architects.

Wittmann, W. (1879). Zur theorie der gewölbe. Zeitschrift für Bauwesen, 29, 61-74. 